\title{
ANTARA KETELADANAN DAN MOTIVASI BELAJAR; PENGARUH DARI KOMPETENSI KEPRIBADIAN GURU DI MTS AZIDDIN MEDAN
}

\author{
Khairuddin Hasan, M.Pd \\ STAIN Teungku Dirundeng Meulaboh \\ khairuddinhasan@,staindirundeng.ac.id
}

\begin{abstract}
Abstrak
Guru diwajibkan untuk memiliki empat kompetensi dalam melaksanakan pendidikan. Empat kompetensi tersebut berkaitan erat dengan kualitas pendidikan. Penelitian ini menyoroti satu dari empat kompetensi, yaitu kompetensi kepribadian. Tujuan dari penelitian ini adalah untuk melihat seberapa besar pengaruh kompetensi kepribadian guru terhadap motivasi belajar siswa. Jenis penelitian yang digunakan adalah penelitian asosiatif dengan pendekatan kuantitatif. Penelitian ini menggunakan analisis regresi sederhana untuk melihat pengaruh variabel (X) terhadap variabel (Y). Hasil penelitian menunjukkan bahwa adanya pengaruh kompetensi kepribadian guru terhadap motivasi belajar siswa. Meskipun pengaruh tersebut tidak kuat, tetapi memberikan kesimpulan bahwa salah satu cara dalam meningkatkan motivasi belajar siswa adalah dengan memperbaiki kompetensi kepribadian guru.
\end{abstract}

Kata kunci: Kompetensi, kepribadian, motivasi belajar.

$\overline{\text { Abstract }}$

Teachers are required to have four competencies in carrying out education. The four competencies are closely related to the quality of education. This study highlights one of four competencies, namely personality competence. The purpose of this study is to see how much influence the teacher's personal competence on student motivation. This type of research is an associative research with a quantitative approach. This study uses simple regression analysis to see the effect of variable $(X)$ on variable (Y). The results showed that the influence of teacher personality competencies on student motivation. Although the effect is not strong, but it concludes that one way to increase student motivation is to improve the teacher's personal competence.

Keywords: Competence, personality, learning motivation

\section{PENDAHULUAN}

Pendidikan adalah sebuah sistem yang diciptakan untuk kemaslahatan umat manusia. Layaknya sebuah sistem, maka pendidikan memiliki komponen-komponen yang saling berhubungan dan membentuk pola kerja. Sistem pendidikan memiliki enam komponen pokok yang salah satunya adalah guru. Guru dalam sistem pendidikan memiliki posisi dan peran sentral. Guru adalah motor penggerak utama 
pendidikan. Dalam UU RI Nomor 14 Tahun 2005 tentang Guru dan Dosen, disebutkan bahwa bahwa guru dan dosen mempunyai fungsi, peran, dan kedudukan yang sangat strategis dalam pembangunan nasional dalam bidang pendidikan sebagaimana dimaksud pada huruf a, sehingga perlu dikembangkan sebagai profesi yang bermartabat.

Dengan peran yang sangat strategis itu pula, guru memiliki konsekuensi berupa tugas dan tanggung jawab yang sama pentingnya. Guru diberi tanggung jawab untuk membangun sumber daya manusia bangsa, meliputi intelektualitasnya, pribadinya dan kemampuan praktiknya. Dalam UU RI No. 14 Tahun 2005 tentang Guru dan Dosen disebutkan bahwa guru adalah pendidik profesional dengan tugas utama mendidik, mengajar, membimbing, mengarahkan, melatih, menilai, dan mengevaluasi peserta didik pada pendidikan anak usia dini jalur pendidikan formal, pendidikan dasar, dan pendidikan menengah.

Dengan tugas yang sedemikian besar, tentu tidak sembarang orang dapat menjadi guru. Untuk itu, dibuatlah kualifikasi kompetensi yang harus dimiliki seorang guru agar dalam penugasannya sesuai dengan tujuan dasar pendidikan. Dalam UU RI yang sama dengan diatas, dikemukakan bahwa seorang guru harus memiliki empat kompetensi yaitu kompetensi pedagogik, professional, sosial dan kepribadian.

Diantara keempat kompetensi tersebut, kompetensi kepribadian layak untuk dijadikan sorotan. Secara sederhana, kompetensi kepribadian paling berhubungan dengan dua kompetensi lainnya yaitu kompetensi pedagogik dan sosial.

102 | BIDAYAH: Volume 11, No. 1, Juni 2020
Menurut Kunandar, kompetensi kepribadian adalah kemampuan personal yang mencerminkan kepribadian yang mantap stabil, dewasa, arif dan berwibawa, menjadi teladan bagi peserta didik dan berakhlak mulia. ${ }^{1}$

Dengan pengertian di atas, dapat diketahui betapa pentingnya kompetensi kepribadian guru. Kompetensi ini tidak dapat dinilai dengan angka diatas kertas atau penilaian konkret lainnya. Karena kompetensi ini berupa nilai yang sesuai dengan agama dan falsafah hidup bangsa.

Antara kepribadian dan motivasi memiliki hubungan yang erat. Kualitas kepribadian seorang guru akan menentukan seberapa besar motivasi belajar siswa dalam kegiatan pembelajaran bersama gurunya. Dalam kiasannya, kepribadian guru adalah mahkota baginya. Tanpa mahkota tersebut siswa akan kehilangan simpati dan motivasi. Karena secara psikologis, siswa menginginkan guru yang mampu menjadi pemimpin dalam segala hal yaitu pengetahuan, praktik dan terlebih lagi nilai. Guru bertanggung jawab terhadap kepribadian siswanya. Untuk itu, kepribadian yang baik secara mutlak harus dimiliki seorang guru. Karena tidak mungkin kepribadian siswa dapat diperbaiki, jika guru tidak memiliki kepribadian. Namun pada realitanya tidak semua guru memiliki kepribadian yang layak sebagaimana profesi yang disandangnya.

Tidak sedikit guru yang menerima antipati dari siswa yang merupakan konsekuensi dari kepribadian yang buruk. Krisis kepribadian guru tersebut meliputi berbagai hal, seperti tidak mematuhi ajaran agama, tidak jujur, tidak

1 Kunandar, Guru Profesional : Implementasi Kurikulum Tingkat Satuan Pendidikan dan Sukses dalam Sertifikasi Guru, (Jakarta : Raja Grafindo, 2007), h. 75. 
bertanggung jawab, tidak memiliki wibawa di depan siswa dan bahkan banyak dikabarkan guru yang melakukan perbuatan asusila terhadap siswanya.

\section{LANDASAN TEORI}

\section{A. Kompetensi Kepribadian Guru}

Kata kompetensi disadur dari bahasa Inggris, yaitu competence yang artinya "kemampuan atau kecakapan". ${ }^{2}$ Dalam bahasa Indonesia, kompetensi berarti "kewenangan (kekuasaan) untuk menentukan (memutuskan sesuatu).

Secara sederhana kompetensi dapat dipahami sebagai kemampuan seseorang dalam suatu bidang. Menurut Soewando kompetensi adalah "sebagai pengetahuan, keterampilan dan nilai-nilai dasar yang direfleksikan dalam kebiasaan berpikir dan bertindak". ${ }^{3}$

Berdasarkan pernyataan di atas maka dapat diketahui bahwa kompetensi adalah pengetahuan, keterampilan, nilai-nilai dasar yang digunakan dalam melaksanakan tugas keprofesionalan seseorang. Artinya kompetensi merupakan beberapa unsur-unsur kemampuan yang saling mengisi dan berkaitan satu sama lain dalam diri seseorang. Masing-masing unsur tersebut memiliki peran yang penting dalam menciptakan suatu kompetensi.

Sedangkan secara terminologi menurut Gregory kepribadian adalah kata yang menandakan ciri pembawaan dan pola kelakuan seseorang yang khas bagi pribadi itu sendiri. Kepribadian meliputi tingkah laku,

2 I. Markus Willy, dkk, Kamus 250 Milyar Inggris-Indonesia Indonesia-Inggris, (Arkola), h. 60 .

3 Soewando, Sistem Pengajaran Kurikulum Berbasis Kompetensi, (Jakarta: Pusat Kurikulum Balitbang Depdiknas, 2002), h. 3. cara berpikir, perasaan, gerak hati, usaha, aksi tanggapan terhadap kesempatan, dan cara sehari-hari dalam berinteraksi dengan orang. ${ }^{4}$

Jadi dapat disimpulkan bahwa kepribadian adalah sifat khas yang ada dalam diri manusia, yang dapat diidentifikasi melalui tingkah laku, cara berpikir, kemampuan, tanggapan terhadap kesempatan dan potensi yang ditampakkan oleh seseorang. Pada dasarnya kepribadian bersifat abstrak dan sulit untuk dinilai. Hal ini dikarenakan kepribadian adalah sesuatu yang tersimpan di pikiran dan hati manusia tentang bagaimana cara dia menyikapi atau menjalani hidupnya.

Kepribadian berhubungan dengan nilainilai yang berkembang dalam suatu masyarakat dan cenderung dihakimi oleh orang-orang sekitar. Setiap masyarakat tentu memiliki nilainilai luhur yang dijadikan patokan bagi tiap-tiap anggota masyarakat. Anggota masyarakat yang berhasil menangkap dan memancarkan nilai tersebut, dianggap sebagai seorang memiliki kepribadian yang baik. Dan sebaliknya, seorang yang tidak berhasil mewujudkan nilai-nilai yang berkembang di masyarakatnya akan dianggap memiliki kepribadian yang buruk.

Kepribadian tidak berdiri sendiri. Artinya kepribadian terbentuk melalui beberapa unsur yang saling berkaitan satu sama lain. Adapun aspek-aspek yang membentuk kepribadian sebagaimana dijelaskan oleh Abin Syamsuddin Makmun, meliputi :

a. Karakter, yaitu konsekuen dalam mematuhi etika perilaku, konsisten atau teguh tidaknya dalam memegang pendirian atau pendapat.

4 Syarkawi, Pembentukan Kepribadian Anak, (Jakarta: Bumi Aksara, 2009), h. 13. 
b. Tempramen, yaitu diposisi reaktif seseorang, atau cepat/lambatnya bereaksi terhadap rangsangan-rangsangan yang datang dari lingkungan.

c. Sikap, sambutan terhadap objek (orang, benda, peristiwa, norma dan sebagainya) yang bersifat positif, negatif dan ambivalen (ragu-ragu).

d. Stabilitas emosional yaitu kadar kestabilan reaksi emosional terhadap rangsangan dari lingkungan.

e. Responsibilitas (tanggung jawab), kesiapan untuk menerima resiko dari tindakan atau perbuatan yang dilakukan.

f. Sosiobilitas, yaitu disposisi pribadi yang berkaitan dengan hubungan interpersonal. ${ }^{5}$

Dari penjabaran di atas, dapat dipahami bahwa unsur-unsur yang membentuk kepribadian adalah apa yang dimiliki dan apa yang dimanifestasikan dalam bentuk perbuatan. Kepribadian bukan hanya tentang apa yang dirasakan, namun juga bagaimana mengungkapkannya melalui interaksi dengan orang lain.

Indikator kompetensi kepribadian guru dijelaskan dalam PP RI No. 74 Tahun 2008 tentang Guru Bab II pasal 3 ayat 5. Di dalam Peraturan Pemerintah tersebut disebutkan poinpoin yang harus dimiliki seorang guru untuk memenuhi kompetensi kepribadiannya. Isi dari Peraturan Pemerintah tersebut adalah sebagai berikut :

Kompetensi kepribadian sekurang-

5 Hasbullah, Dasar-Dasar Ilmu Pendidikan, (Jakarta: Raja Grafindo Persada, 1999), h. 103.

104 | BIDAYAH: Volume 11, No. 1, Juni 2020 kurangnya mencakup kepribadian yang:

a. beriman dan bertakwa;

b. berakhlak mulia;

c. arif dan bijaksana;

d. demokratis;

e. mantap;

f. berwibawa;

g. stabil;

h. dewasa;

i. jujur;

j. sportif;

k. menjadi teladan bagi peserta didik dan masyarakat;

1. secara obyektif mengevaluasi kinerja sendiri; dan

m. mengembangkan diri secara mandiri dan berkelanjutan.

\section{B. Motivasi Belajar}

Secara sederhana motif adalah dorongan yang ada dalam diri manusia, yang dapat berasal dari dalam dirinya atau dari luar. Jika berasal dari dalam diri, maka motif tersusun dari kebutuhan-kebutuhan fisik dan psikisnya. Sedangkan jika berasal dari luar, diawali dengan adanya pengetahuan dan pengalaman tentang sesuatu. Dengan pengetahuan dan pengalaman, maka seseorang akan menentukan keinginannya dan melakukan sesuatu untuk mewujudkannya.

Sedangkan motivasi secara prinsip terkait dorongan yang terdapat pada diri seseorang untuk melakukan sesuatu. Tiga kata kunci dalam motivasi adalah sebagai berikut: (a) dalam motivasi terdapat dorongan yang menjadikan seseorang mengambil tindakan atau tidak mengambil tindakan, (b) dalam motivasi terdapat satu pertimbangan apakah harus memprioritaskan tindakan alternatif, baik 
itu tindakan A atau tindakan B, dan (c) dalam motivasi terdapat lingkungan yang memberi atau menjadi sumber masukan atau pertimbangan seseorang untuk melakukan tindakan pertama atau kedua. ${ }^{6}$

Menurut Mc.Donald, motivasi adalah perubahan energi dalam diri seseorang yang ditandai dengan munculnya "feeling" dan didahului dengan tanggapan terhadap adanya tujuan. Dan pengertian yang dikemukakan Mc.Donald ini mengandung tiga elemen penting.

1. Bahwa motivasi itu mengawali terjadinya perubahan energi pada diri setiap individu manusia. Perkembangan motivasi akan membawa beberapa perubahan energi di dalam sistem "neurophysiological" yang ada pada organisme manusia (walaupun motivasi itu muncul dari dalam diri manusia), penampakannya akan menyangkut kegiatan fisik manusia.

2. Motivasi ditandai dengan munculnya, rasa/"feeling", afeksi seseorang. Dalam hal ini motivasi relevan dengan persoalan-persoalan kejiwaan, afeksi dan emosi yang dapat menentukan tingkah laku manusia.

3. Motivasi akan dirangsang karena adanya tujuan, jadi motivasi dalam hal ini sebenarnya merupakan respons dari suatu aksi, yakni tujuan. Motivasi memang muncul dari dalam diri manusia, tetapi kemunculannya karena terangsang/terdorong oleh adanya unsur

Mardianto,PsikologiPendidikan:LandasanBagi PengembanganStrategiPembelajaran,(Bandung: Citapustaka Media Perintis, 2009), h. 162. lain, dalam hal ini adalah tujuan. Tujuan ini akan menyangkut soal kebutuhan. ${ }^{7}$

Abin Syamsuddin mengatakan bahwa meskipun para ahli mendefinisikannya dengan cara dan gaya berbeda, namun esensinya menuju kepada maksud yang sama, bahwa motivasi merupakan ;

1. Suatu kekuatan (power) atau tenaga (forces) atau daya (energy); atau

2. Suatu keadaan yang kompleks ( $a$ complex state) dan kesiapsediaan (preparatory set) dalam diri individu (organism) untuk bergerak (to move, motion, motive) ke arah tujuan tertentu, baik disadari maupun tidak disadari. ${ }^{8}$

Motivasi sekurangnya memiliki tiga unsur pokok. Adapun ketiga unsur tersebut adalah :

a. Dorongan yang menjadi penyebab seseorang melakukan suatu tindakan.

b. Arahan, bahwa motivasi mengarahkan seseorang untuk memilih suatu tindakan dari beberapa tindakan yang bisa dilakukan.

c. Keadaan di sekitar, yang menjadikan seseorang harus bertindak.

Motivasi memiliki beberapa fungsi, yaitu :

1. Mendorong timbulnya kelakuan atau perbuatan. Tanpa motivasi tidak akan

7 Sardiman, A.M, Interaksi dan Motivasi Belajar-Mengajar, (Jakarta: Rajawali Pers, 2011), h. 74.

8 Abin Syamsuddin Makmun, Psikologi Pendidikan, (Bandung: PT. Remaja Rosdakarya, 2004), h. 37 . 
timbul perbuatan seperti belajar.

2. Sebagai pengarah, artinya mengarahkan perbuatan kepada pencapaian tujuan yang diinginkan.

3. Sebagai penggerak. Ia berfungsi sebagai mesin bagi mobil. Besar kecilnya motivasi akan menentukan cepat atau lambatnya suatu pekerjaan. ${ }^{9}$

Belajar adalah kegiatan sistemik yang tidak bisa dilakukan begitu saja. Dalam belajar, seseorang butuh motivasi dan tujuan yang ingin dicapai. Dengan dasar inilah, maka motivasi belajar sangat besar perannya bagi siswa. Dengan motivasi belajar yang kuat dan konsisten, maka siswa akan mampu melakukan kegiatan sistemik tersebut (belajar) dengan baik dan mewujudkan tujuannya. Sebaliknya, siswa dengan motivasi belajar yang lemah akan kesulitan melakukan aktivitas belajar dan cenderung pasif jika berada dalam situasi pembejalaran misalnya di dalam kelas.

Dimyati dan Mudjiono menjelaskan bagaimana pentingnya motivasi belajar bagi siswa, sebagai berikut:

a. Menyadarkan kedudukan pada awal belajar, proses, dan hasil akhir; contohnya setelah siswa membaca suatu bab buku bacaan, dibandingkan dengan teman sekelasnya yang juga membaca bab buku bacaan tersebut; ia kurang berhasil menangkap isi, maka ia terdorong untuk membaca lagi.

b. Menginformasikan tentang kekuatan usaha belajar, yang dibandingkan dengan teman sebaya; sebagai ilustrasi, jika terbukti usaha belajar siswa belum

9 Mardianto, Psikologi Pendidikan ..., h. 168

106 | BIDAYAH: Volume 11, No. 1, Juni 2020 memadai, maka ia berusaha setekun temannya yang belajar dan berhasil.

c. Mengarahkan kegiatan belajar; sebagai ilustrasi, sete;ah ia ketahui bahwa dirinya belum belajar serius, terbukti banyak bersenda gurau misalnya, maka ia akan merubah perilaku belajarnya.

d. Membesarkan semangat belajar; sebagai ilustrasi, jika ia telah menghabiskan dana belajar dan masih ada adik yang dibiayai orang tua, maka ia berusaha agar cepat lulus.

e. Menyadarkan tentang adanya perjalanan belajar dan kemudian bekerja (diselaselanya ada istirahat atau bermain) yang bersinambungan; individu dialtih untuk menggunakan kekuatannya sedemikian rupa sehingga dapat berhasil. Sebagai ilustrasi, setiap hari siswa diharapakan untuk belajar di rumah, membantu pekerjaan orang tua, dan bermain dengan teman sebaya; apa yang dilakukan diharapkan dapat berhasil memuaskan. ${ }^{10}$

Dari penjelasan di atas dapat diketahui betapa pentingnya motivasi belajar bagi siswa. Lebih dari itu, motivasi belajar harus disadari oleh siswa. Dengan kesadaran tentang motivasi belajar dan pentingnya motivasi tersebut, maka akan membantu kegiatan belajar siswa agar berjalan dengan baik.

\section{METODOLOGI PENELITIAN}

Penelitian ini dilakukan di Madrasah Tsanawiyah Aziddin Medan. Jenis penelitian yang digunakan adalah penelitian asosiatif

10 Dimyati dan Mudjiono, Belajar dan Pembelajaran, (Jakarta: PT. Rineka Cipta, 2006),h. 85 
dengan pendekatan kuantitatif. Penelitian ini bertujuan untuk menghitung besarnya pengaruh kompetensi kepribadian guru terhadap motivasi belajar siswa.

Populasi dalam penelitian ini berjumlah 30 orang .Menurut Suharsimi Arikunto bahwa "untuk sekedar ancar-ancar apabila subjek kurang dari 100 orang, lebih baik diambil semua sehingga penilitiannya merupakan penelitian populasi." ${ }^{11}$.. Berdasarkan itu, maka subjek dalam penelitian ini adalah seluruh populasi.

Metode pengumpulan data dengan observasi, dokumentasi dan angket. Teknik dokumentasi digunakan untuk mengetahui daftar guru dan informasi identitas guru beserta riwayat pendidikannya. Angket dalam penelitian ini adalah angket semi terbuka, yaitu responden diberikan kesempatan untuk menentukan jawaban sesuai dengan pilihan yang diberikan. Pilihan jawaban dari responden akan dinilai dengan Skala Likert.

Teknik analisis data yang digunakan adalah teknik analisis regresi sederhana. Analisis regresi sederhana dilakukan untuk mengetahui besarnya pengaruh antara dua variable yaitu kompetensi kepribadian guru terhadap motivasi belajar siswa. Persamaannya $\mathrm{Y}=\alpha+\beta \mathrm{X}+\varepsilon$, dimana:

$\mathrm{Y}=$ variabel dependen (motivasi belajar siswa);

$\mathrm{X}=$ variabel independen (kompetensi kepribadian guru);

$\alpha=$ konstanta;

$\beta=$ koefisien regresi;

$\varepsilon=$ variabel lain di luar lingkup penelitian.

\section{HASIL DAN PEMBAHASAN}

11 Suharsimi Arikunto, Prosedur Penelitian Suatu Pendekatam Praktek, (Jakarta : Rineka Cipta, 2006), hl. 107
Berdasarkan dari hasil analisis yang telah dilakukan, maka ditemukan bahwa $\mathrm{R}$ square yang menunjukkan seberapa besar kontribusi antara variabel independen terhadap variable dependen. Ditemukan bahwa variabel kompetensi kepribadian guru terhadap motivasi belajar siswa mempunyai pengaruh sebesar 0,131 atau $13,1 \%$. Sedangkan $86,9 \%$ dipengaruhi variabel lain yang berada di luar jangkauan penelitian.

Kemudian dilakukan uji regresi sederhana untuk melihat seberapa besar signifikansi antara variabel $\mathrm{X}$ terhadap variabel Y. Selain itu, uji ini juga untuk melihat apakah motivasi belajar siswa meningkat apabila kompetensi kepribadian guru meningkat.

\section{Regregsi Sederhana}

\begin{tabular}{|c|c|c|c|c|c|}
\hline Model & \multicolumn{2}{|c|}{$\begin{array}{c}\text { Unstandardized } \\
\text { Coefficients }\end{array}$} & $\begin{array}{c}\text { Standardized } \\
\text { Coefficients }\end{array}$ & T & Sig. \\
\cline { 2 - 6 } & B & Std. Error & Beta & & \\
\hline (constant) & 45,382 & 12,001 &, 359 & 5,158 &, 000 \\
Kompetensi &, 225 &, 134 & & 2,403 &, 032 \\
Kepribadian & & & & & \\
\hline
\end{tabular}

Tabel dependen variabel motivasi belajar

Pada tabel dinyatakan bahwa nilai signifikansi pada tabel Sig. sebesar 0,032 dengan taraf signifikan yang sudah ditentukan sebesar 0,05 yang dinyatakan apabila nilai signifikan lebih kecil dari taraf signifikan yang telah ditentukan, maka dikatakan bahwa variabel kompetensi kepribadian guru (X) terhadap motivasi belajar siswa $(\mathrm{Y})$ berpengaruh signifikan. Setelah dilakukan analisis data menggunakan SPSS Statistik versi 17.0, dapat ditarik kesimpulan bahwa nilai signifikan lebih kecil dari taraf signifikan, yaitu $0,032 \leq 0,05$.

Untuk itu, maka dapat disimpulkan bahwa ada pengaruh yang signifikan antara variabel kompetensi kepribadian guru terhadap 
motivasi belajar siswa. Hasil persamaan regresi dari tabel di atas :

$$
\mathrm{Y}=45,382+0,225 \mathrm{X}
$$

Dimana:

Y : Motivasi Belajar Siswa

$\mathrm{X}$ : Kompetensi Kepribadian Guru

Sedangkan dari tabel coefficients ditemukan bahwa nilai konstanta 45,382 yang menyatakan jika kompetensi professional guru naik satu poin saja maka motivasi belajar siswa akan turut naik menjadi 0,225. Jadi salah satu cara guru untuk memperbaiki motivasi belajar siswanya adalah dengan memperbaiki kompetensi kepribadian guru.

Penelitian ini menunjukkan beberapa hal penting demi perbaikan motivasi belajar siswa dan kompetensi kepribadian guru. Kompetensi kepribadian guru memberikan kontribusi positif terhadap naik turunnya motivasi belajar siswa. Hal ini dapat dilihat dari hasil uji regresi bahwa $\mathrm{R}$ square memiliki nilai 0,131 yang berarti memiliki pengaruh yang lemah dengan koefisien korelasi sebesar 0,359. Dari persamaan regresi menunjukkan bahwa apabila kompetensi kepribadian guru meningkat maka motivasi belajar siswa juga turut meningkat, dengan melihat $\mathrm{Y}=45,382+0,225 \mathrm{X}$.

Berdasarkan UU RI Nomor 14 Tahun 2005 tentang Guru dan Dosen, guru sebagai motor penggerak utama pendidikan yang dilabeli dengan kata profesional harus memenuhi syarat sebelum menyandang predikat tersebut. Adalah empat kompetensi yang wajib disandang oleh seorang guru sebelum dianggap sebagai tenaga profesional. Yaitu sebagai mana yang tercantum dalam UU yang sama Bab IV Pasal 10 ayat 1 yang berbunyi bahwa kompetensi guru sebagaimana dimaksud dalam pasal 8 meliputi kompetensi pedagogik, kompetensi kepribadian, kompetensi sosial, dan kompetensi profesional yang diperoleh melalui pendidikan profesi.

Dari empat kepribadian guru yang dikemukakan dalam UU tersebut, maka kompetensi kepribadian layak untuk disoroti. Kompetensi kepribadian berkaitan dengan sifat dan sikap guru dalam kehidupan sehari-hari, tidak hanya di sekolah namun juga di keluarga dan masyarakat.

Kompetensi kepribadian guru sangat berpengaruh terhadap kredibilitas di mata para siswanya. Guru yang memiliki kepribadian yang baik, akan lebih dipercaya siswa dalam proses pembelajaran dibanding guru yang memiliki kepribadian kurang baik.

Dalam arti sederhananya, kualitas kompetensi kepribadian seorang guru akan menentukan apakah guru tersebut layak untuk dijadikan sebagai teladan oleh siswanya atau tidak. Mengingat guru tidak hanya bertugas dalam dalam mengajar, namun juga mendidik. Mendidik berarti bertanggung jawab terhadap kognitif, afektif dan psikomotorik siswa. Dalam mendidik, butuh lebih dari sekedar pemberian materi yaitu contoh nyata tentang suatu kebaikan. Dan contoh yang paling baik bagi siswa adalah gurunya sendiri. Dan guru yang layak untuk dijadikan teladan adalah guru yang memiliki kompetensi kepribadian yang baik pula.

Adapun kaitan antara kompetensi kepribadian dengan motivasi adalah bagaimana guru mampu menunjukkan dirinya sebagai seorang yang memiliki kredibilitas dan siswanya merasa bahwa gurunya layak untuk mendidik 
mereka. Motivasi adalah dorongan untuk melakukan sesuatu dengan tujuan tertentu.

Motivasi dalam konteks belajar, adalah dorongan bagi siswa agar belajar dengan tujuan tertentu. Salah satu yang dapat menjadi sumber motivasi siswa adalah gurunya sendiri. Guru yang memiliki kompetensi kepribadian yang baik tentu akan menjadi motivator yang baik pula demi kegiatan pembelajaran yang lebih baik.

Berdasarkan instrumen penelitian yang digunakan, maka ditemukan bahwa kunci dari kompetensi kepribadian guru yang mempengaruhi motivasi belajar siswa adalah keteladanan. Siswa menganggap guru adalah role model yang paling ideal dalam bertingkah laku. Siswa menganggap bahwa sikap keseharian guru adalah hasil dari buah pikir dan proses pendidikan yang sudah dilalui, sehingga layak untuk ditiru.

Sedangkan motivasi belajar adalah ruh dari jalannya proses pendidikan. Tanpa motivasi belajar siswa yang terus dipupuk dan dijaga, maka pembelajaran yang diikuti siswa hanya akan berjalan hampa tanpa bekas. Kesuksesan dalam mencapai tujuan pembelajaran dapat diperoleh jika guru mampu mengelola motivasi belajar siswa.

Dimyanti dan Mudjiono mengatakan bahwa motivasi belajar merupakan segi kejiwaan yang mengalami perkembangan artinya terpengaruh oleh kondisi fisiologis dan kematangan psikologis anak. Motivasi seseorang dapat bersumber dari internal dan eksternal, motivasi memang mendorong terus, dan memberikan energi pada tingkah laku. ${ }^{12}$

Kemudian menurut Nanang dan

12 Dimyanti dan Mudjiono, Belajar ..., h. 78
Cucu Sahana bahwa motivasi belajar merupakan kekuatan, daya pendorong atau alat pembangunan kesediaan dan keinginan yang kuat dalam diri siswa untuk belajar aktif, kreatif dan inovatif, serta menyenangkan dalam rangka baik dalam kognitif, afektif maupun psikomotorik anak. ${ }^{13}$

Jika guru ingin meningkatkan kualitas pembelajaran dan capaiannya, maka salah satu cara yang dapat ditempuh adalah dengan memperbaiki kompetensi kepribadian. Memperbaiki kompetensi kepribadian akan berpengaruh pada peningkatan motivasi belajar. Artinya dengan memperbaiki satu hal saja, maka proses pembelajaran dapat lebih mudah berjalan dengan kualitas yang meningkat.

Sebaliknya, jika guru lalai dalam menjaga dan meningkatkan kompetensi kepribadian maka akan berdampak sistemis terhadap motivasi belajar siswa. Guru yang tetap menjalankan tugas dengan kompetensi kepribadian yang rendah, alih-alih dapat memperbaiki pendidikan, malah akan mendegradasinya seiring dengan menurunnya motivasi belajar siswa.

Perbaikan dan peningkatan kompetensi kepribadian guru tidak hanya menjadi tanggung jawab guru, tapi menjadi tanggung jawab pihak madrasah dan pemerintah. Tentu saja proses perbaikan kompetensi kepribadian bukanlah proyek satu malam. Butuh proses panjang dan kerja sama antar semua pihak agar dapat terlaksana dengan baik.

Perbaikan kompetensi ini bisa diawali dengan kesadaran guru terlebih dahulu akan pentingnya keteladanan pada diri mereka.

13 Nanang Hanafiah dan Cucu Sahana, Konsep Strategi Pembelajaran, (Bandung : Refika Aditama, 2010), h. 26 
Kesadaran ini akan menjadi pondasi penting agar dapat disusun langkah sistematis selanjutnya. Dengan adanya kesadaran personal dari guru, maka perbaikan kompetensi kepribadian tidak sekedar menjadi bukti di atas kertas saja, tapi dapat dilihat dari keseharian guru di lingkungan madrasah dan masyarakat.

\section{KESIMPULAN}

Berdasarkan hasil penelitian yang telah dilakukan, ditemukan bahwa ada hubungan antara kompetensi kepribadian guru dan motivasi belajar siswa. Hubungan tersebut meski tidak kuat, tetapi tetap berpengaruh. Kompetensi kepribadian guru memberikan kontribusi positif terhadap motivasi belajar siswa. Indikatornya adalah hasil uji regresi bahwa $\mathrm{R}$ square memiliki nilai 0,131 yang berarti memiliki pengaruh mesikpun tidak kuat dengan koefisien korelasi sebesar 0,359. Dari persamaan regresi menunjukkan bahwa apabila kompetensi kepribadian guru meningkat maka motivasi belajar siswa juga turut meningkat, dengan melihat $\mathrm{Y}=45,382+0,225 \mathrm{X}$.

Dengan hasil tersebut, maka guru seyogyanya dapat meningkatkan kompetensi kepribadian. Perbaikan kompetensi kepribadian akan berdampak kepada motivasi belajar siswa. Memperbaiki dua hal krusial tersebut akan berpengaruh besar pada keberhasilan pencapaian pembelajaran.

Pihak madrasah dan pemerintah terkait pun harus ikut bertanggung jawab membantu guru dalam membangun dan meningkatkan kompetensi kepribadian. Dengan adanya kerja integratif antar pihak-pihak tersebut, diharapkan kualitas pembelajaran menjadi lebih baik dan jauh lebih bermakna.

\section{DAFTAR PUSTAKA}

Arikunto, Suharsimi. Prosedur Penelitian Suatu Pendekatam Praktek. Jakarta: Rineka Cipta, 2006.

Dimyati dan Mudjiono. Belajar dan Pembelajaran. Jakarta: PT. Rineka Cipta, 2006. Hanafiah, Nanang dan Cucu Sahana. Konsep Strategi Pembelajaran. Bandung: Refika Aditama, 2010.

Hasbullah. Dasar-Dasar Ilmu Pendidikan. Jakarta: Raja Grafindo Persada, 1999.

I. Markus Willy, dkk. Kamus 250 Milyar Inggris-Indonesia Indonesia-Inggris, Arkola.

Kunandar. Guru Profesional

Implementasi Kurikulum Tingkat Satuan Pendidikan dan Sukses dalam Sertifikasi Guru. Jakarta: Raja Grafindo, 2007.

Makmun, Abin Syamsuddin. Psikologi Pendidikan. Bandung: PT. Remaja Rosdakarya, 2004.

Mardianto. Psikologi Pendidikan : Landasan Bagi Pengembangan Strategi Pembelajaran. Bandung: Citapustaka Media Perintis, 2009.

Sardiman, A.M. Interaksi dan Motivasi Belajar-Mengajar. Jakarta: Rajawali Pers, 2011. Soewando. Sistem Pengajaran Kurikulum Berbasis Kompetensi. Jakarta: Pusat Kurikulum Balitbang Depdiknas, 2002.

Syarkawi. Pembentukan Kepribadian Anak. Jakarta: Bumi Aksara, 2009. 